\title{
THE INFLUENCE OF TOP MANAGEMENT COMMITMENT ON FIRM PRODUCTIVITY THROUGH TOTAL QUALITY MANAGEMENT AND MANAGEMENT ACCOUNTING INFORMATION SYSTEM ${ }^{1)}$
}

\author{
Roebiandini Soemantri \\ Lecturer remain in economics and Business faculty, University of Padjadjaran, Indonesia
}

\begin{abstract}
This study examines the influence of top management commitment on firm productivity through implementation of total quality management and management accounting information systems. The research employed explanatory survey method. Data for this study were drawn from a survey 73 Indonesia Manufacturing Firms having sertification of ISO 9000 series from 2004 up to 2006. The respondents of this research are production manager of each firm. Data were collected by indirect communication based on a questionnaire and study of documentation. Descriptive statistics were used to data analysis based on weighted mean score and path analysis. This study used primary data and secondary data. The results are as follows : (1) there is a positive and significant influence of top management commitment toward implementation of total quality management; (2)there is a positive and significant influence of top management commitment on management accounting information systems; (3) there is a positive and significant influence of implementation of total quality management and management accounting information systems to firm productivity; (4) there is a positive and significant influence of top management commitment to firm productivity through implementation of total quality management; (5) there is a positive and significant influence of top management commitment to productivity through management accounting information systems; (6) there is a positive and significant influence of top management commitment on firm productivity through implementation of total quality management and management accounting information systems.
\end{abstract}

Keywords : Top Management Commitment, Firm Productivity, Total Quality Management and Management Accounting Information Systems.

\section{ABSTRAK}

Penelitian ini mengkaji pengaruh komitmen manajemen puncak terhadap produktivitas melalui implementasi manajemen mutu terpadu dan sistem informasi akuntansi manajemen. Metode yang digunakan adalah survei penjelasan. Survei dilakukan terhadap 69 perusahaan yang telah memperoleh sertifikat ISO seri 9000 sejak tahun 2004-2006. Responden penelitian ini adalah manajer produksi dari setiap perusahaan. Teknik pengumpulan data dilakukan dengan komunikasi tidak langsung dengan bantuan instrumen berupa kuesioner dan studi dokumentasi. Analisis data dilakukan secara deskriptif dengan bantuan statistika rata-rata nilai terbobot dan secara inferensial dengan statistika analisis jalur. Data yang digunakan adalah data primer dan data sekunder. Hasil penelitian menunjukkan bahwa: (1) Komitmen manajemen puncak berpengaruh positif dan bermakna terhadap implementasi manajemen mutu terpadu; (2) Komitmen manajemen puncak berpengaruh positif dan bermakna terhadap sistem informasi akuntansi manajemen; (3) Implementasi manajemen mutu terpadu dan sistem informasi akuntansi manajemen berpengaruh positif dan bermakna terhadap produktivitas perusahaan; (4) Komitmen manajemen puncak melalui implementasi manajemen mutu terpadu berpengaruh positif dan bermakna terhadap produktivitas; (5) Komitmen manajemen puncak melalui sistem informasi akuntansi manajemen berpengaruh positif dan bermakna terhadap produktivitas; (6) Komitmen manajemen puncak melalui implementasi manajemen mutu terpadu dan sistem informasi akuntansi manajemen berpengaruh positif dan bermakna terhadap produktivitas;

Kata kunci: komitmen manajemen puncak, produktivitas perusahaan, manajemen mutu terpadu dan sistem informasi akuntansi manajemen.

\footnotetext{
Study on Indonesia Manufacturing Firms Having Certification of ISO 9000 Series
} 


\section{PENDAHULUAN}

Setelah krisis ekonomi melanda kawasan Asia pada tahun 1997, maka sejak tahun 2000 terjadi restrukturisasi perekonomian di Asia yang mengarah kepada pemulihan ekonomi. Negara-negara industri seperti Korea, Taiwan, Singapura dan terutama China mengalami kemajuan industri yang cukup pesat di Asia dan memberikan pengaruh yang signifikan terhadap liberalisasi perdagangan di seluruh Asia. Keadaan ini menyebabkan dunia bisnis di Asia menjadi sangat kompetitif termasuk di Indonesia (Williamson, 2005).

Dalam menghadapi perubahan tersebut perusahaan manufaktur di Indonesia dihadapkan pada tantangan berat untuk mempertahankan pangsa pasar, mengingat daya saing produk perusahaan Indonesia di pasar global dari waktu ke waktu mengalami penurunan (WEF, IMD Yearbook, 2008).

Delapan faktor kunci yang menyebabkan rendahnya tingkat daya saing perusahaan Indonesia, yaitu: (1) Kebijakan ekonomi protektif yang menyebabkan kurang inovatif dan harga mahal; (2) Peran dan prestasi lembaga-lembaga ekonomi nasional yang di bawah standar; (3) Perkembangan dan difusi teknologi yang berjalan lamban; (4) Lemahnya penegakan hukum, sehingga mudah terjadi Korupsi, Kolusi dan Nepotisme (KKN); (5) Sifat dan struktur pasar kerja yang tidak fleksibel dan tidak dinamis; (6) Kompetensi Sumber Daya Manusia (SDM) yang rendah; (7) Rasio modal per tenaga kerja relatif rendah; dan (8) Tingkat pertumbuhan produktivitas rendah (makro, mikro, partial dan total) (Depperin, 2008; World Bank, 2008; JETRO, 2008).

Penurunan produktivitas perusahaan manufaktur di Indonesia diproyeksikan pada tahun 2009 mencapai 10-20 persen. Faktor penyebab penurunan produktivitas perusahaan manufaktur di antaranya: (1) Melemahnya pasar ekspor, berdampak pada menyempitnya pasar, selanjutnya mengakibatkan pendapataan sales semakin mengecil, dan didorong oleh kenaikan harga komponen kandungan impor dengan biaya tinggi, (2) Lemahnya penguasaan teknologi, yang membuat industri manufaktur ini akan semakin melemah; (3) Rendahnya kualitas SDM sebagaimana tercermin dari tingkat pendidikan tenaga kerja industri; (4) Belum terintegrasinya UKM di Indonesia dalam satu mata rantai pertambahan nilai dengan industri skala besar; (5) Kurang sehatnya iklim persaingan karena banyak subsektor industri yang beroperasi dalam kondisi mendekati monopoli, setidaknya oligopoli (Wanandi, 2008; BPS, 2008).

Dick et.al. (2001) dalam penelitiannya di Australia dan New Zealand mengungkapkan bahwa tidak terbukti adanya hubungan antara perolehan sertifikat ISO seri 9000 dengan kinerja perusahaan. Namun penelitian yang dilakukan Roger (2002) pada perusahaan-perusahaan di Indonesia yang telah mendapat sertifikat ISO seri 9000 menunjukkan bahwa perusahaan-perusahaan tersebut dapat meningkatkan produktivitas.

Pengukuran produktivitas di tingkat perusahaan merupakan faktor penting untuk mengetahui produktivitas perusahaan yang telah dicapai dan merupakan dasar untuk perencanaan peningkatan produktivitas perusahaan di masa yang datang. Produktivitas perusahaan adalah kemampuan perusahaan mengelola seluruh sumber daya yang dimiliki untuk menghasilkan sejumlah nilai tambah atau nilai kemakmuran (Dewan Produktivitas Nasional, 2008; http://www.iso.ch).

Manajemen dalam suatu perusahaan harus punya komitmen yang tinggi dalam memahami pentingnya Sistem Informasi Akuntansi Manajemen (SIAM) dan dapat menggunakannya untuk memotivasi seluruh karyawan untuk pencapaian strategi Manajemen Mutu Terpadu (Selto, et.al, 1995; Banker et.al., 1994). Desain SIAM menyediakan informasi umpan balik bagi karyawan, sehingga mereka dapat mengukur apakah hasil pekerjaan mereka sesuai dengan target yang ingin dicapai dari implementasi MMT. Selain itu desain SIAM harus mencakup sistem penghargaan yang sesuai dengan ukuran-ukuran kinerja yang relevan dengan MMT (Sim dan Killough, 1998). Sumber keunggulan pemanufakturan dalam lingkungan persaingan yang ketat adalah inovasiinovasi yang berkelanjutan dan keunggulan tersebut dihasilkan oleh orang-orang yang kreatif yang merupakan sumber utama untuk melakukan perbaikan mutu (Hiromoto, 1991). Akuntansi manajemen harus dipahami sebagai "accounting for getting people to do the desired jobs well". Hal ini sejalan dengan hasil penelitian Sim dan Killough (1998), bahwa interaksi antara MMT dengan SIAM akan menghasilkan sinergi berupa pencapaian keunggulan perusahaan manufaktur.

Berdasarkan uraian tersebut kajian tentang Komitmen Manajemen Puncak, Manajemen Mutu Terpadu dan Sistem Informasi Akuntansi Manajemen serta dampaknya terhadap Produktivitas menarik untuk diteliti, karena akan bermanfaat bukan saja bagi 
pengembangan ilmu pengetahuan khususnya ilmu Akuntansi Manajemen dan Produktivitas, tetapi juga akan bermanfaat bagi perusahaan dalam menginventarisasi alternatif peningkatan produktivitas perusahaan dengan mengkaji komitmen manajemen puncak melalui manajemen mutu terpadu dan sistem informasi akuntansi manajemen.

Tujuan penelitian ini adalah untuk memperoleh bukti empirik tentang: (1) Pengaruh Komitmen Manajemen Puncak terhadap Manajemen Mutu Terpadu; (2) Pengaruh Komitmen Manajemen Puncak terhadap Sistem Informasi Akuntansi Manajemen; (3) Pengaruh Manajemen Mutu Terpadu dan Sistem Informasi Akuntansi Manajemen secara simultan dan parsial terhadap Produktivitas Perusahaan; (4) Pengaruh Komitmen Manajemen Puncak melalui Manajemen Mutu Terpadu terhadap Produktivitas Perusahaan; (5) Pengaruh Komitmen Manajemen Puncak melalui Sistem Informasi Akuntansi Manajemen terhadap Produktivitas Perusahaan; (6) Pengaruh Komitmen Manajemen Puncak melalui Manajemen Mutu Terpadu dan Sistem Informasi Akuntansi Manajemen terhadap Produktivitas Perusahaan.

\section{KAJIAN PUSTAKA}

Teori Komitmen Manajemen (Commitment Management Theony dari Kreitner dan Kinicki (2005); Yulk (2005); Velasquez (2005); Griffin (2005); Luthan (2006); dan Robbins (2007) menyatakan bahwa komitmen organisasi banyak dikaji dalam penelitian tentang perilaku organisasi. Yulk, (2005); Griffin, (2005); Luthan, (2006); dan Robbin, (2007) mengemukakan bahwa komitmen bukan proses satu pihak, melainkan proses saling keterkaitan antara individu dengan organisasi. Pandangan tradisional menganggap bahwa komitmen sebagai proses sepihak di mana organisasi memaksakan kesetiaan dan pengabdian dari para anggotanya. Kedatangan individu ke dalam organisasi dianggap hanya sekedar untuk memenuhi kebutuhan dan kepuasan individu. Dalam pandangan modern, komitmen adalah kebutuhan timbal balik antara organisasi dengan anggotanya dan mengupayakan agar orientasi nilai dan kebutuhan dari anggota sejalan dengan orientasi nilai dan tujuan organisasi. Komitmen organisasi yang diwakili oleh komitmen manajemen puncak menunjukkan bahwa keberadaan komitmen manajemen puncak memegang peranan penting dalam menentukan keberhasilan atau kegagalan perusahaan. Persoalan pertama yang dihadapi manajemen puncak dalam menjalankan komitmennya adalah apakah manajemen puncak memiliki komitmen terhadap birokrasi dan profesinya. Karyawan sering merasa dibebani oleh keputusan birokrasi, misalnya bertambahnya jam kerja akibat keharusan untuk memenuhi target tertentu. Di sisi lain manajemen puncak harus menjalankan profesinya yaitu mencapai sasaran perusahaan, antara lain peningkatan efisiensi, sehingga menyebabkan adanya pembatasan jumlah karyawan. Kondisi ini melahirkan keharusan bahwa komitmen itu harus ditujukan kepada kedua kepentingan tersebut. Masalah kedua, apakah yang menjadi dasar pemeliharaan komitmen manajemen puncak. Sebagaimana pekerjaan lain, manajemen puncak harus memelihara komitmennya atas dasar kecintaan dan tanggung jawabnya terhadap stakeholder. (2)

Teori Sistem Informasi Akuntansi Manajemen, McLeod dan Schell (2008) menyatakan bahwa pemecahan masalah adalah aktivitas terpenting yang harus dilakukan oleh seorang manajer, merupakan suatu gambaran yang terlalu disederhanakan. Pemecahan masalah tidak akan efektif tanpa adanya informasi yang relevan. Davis dan Olson, (1984); Heitger dan Matulich, (1986); Bursh dan Grundnitski, (1986); Mascove dan Simskin, (1990); Anthony et al., (1999); Laudon dan Jane, (2005); Hongren, (2005); Hansen dan Mowen, (2005), menyatakan bahwa informasi adalah fakta, data, pengamatan, persepsi, atau sesuatu yang lain, yang menambah pengetahuan. Information System Theory, dari Laudon dan Laudon (2005) menyatakan bahwa dewasa ini pengetahuan tentang sistem informasi bagi manajer bersifat mutlak sebab tidak ada organisasi yang tidak memerlukan informasi.

Sistem Informasi Akuntansi Manajemen (SIAM) merupakan salah satu konsep yang berada dalam teori akuntansi manajemen yang menyediakan informasi bagi manajemen untuk pengambilan keputusan bisnis.

Teori Manajemen Mutu Terpadu, dari Deming (1982), Sim dan Killough (1998); Gunasekaran (1998); Sharma (2000); Blocher (2005), menyatakan bahwa MMT adalah suatu pendekatan manajemen yang dapat memperbaiki produktivitas organisasi (perusahaan). Teori ini menekankan pada perbaikan berkesinambungan terhadap proses produksi dengan cara mengeliminasi pemborosan, memperbaiki mutu, mengembangkan keterampilan orang dan mengurangi biaya produksi. 
Teori Produktivitas, dari Mohanty (1998); Porwal (2002), Samuelson (2003); Vora (2003); Kreitner dan Kinicki (2005); Luthan, (2006); Robbins (2007), Teori ini mengemukakan bahwa produktivitas adalah suatu ukuran untuk mengetahui bagaimana sumber-sumber daya yang ada dalam perusahaan dikelola untuk mencapai sasaran-sasaran tertentu yang dinyatakan secara kualitatif maupun kuantitatif.
Pada umumnya produktivitas diukur berdasarkan hubungan antara input dengan output. Dalam arti luas, produktivitas adalah ukuran yang digunakan untuk menilai peranan perilaku manusia dalam melakukan proses merubah inputmenjadi output.

Berdasarkan kerangka pemikiran tersebut dapat dijelaskan paradigma penelitian ini sebagai berikut :

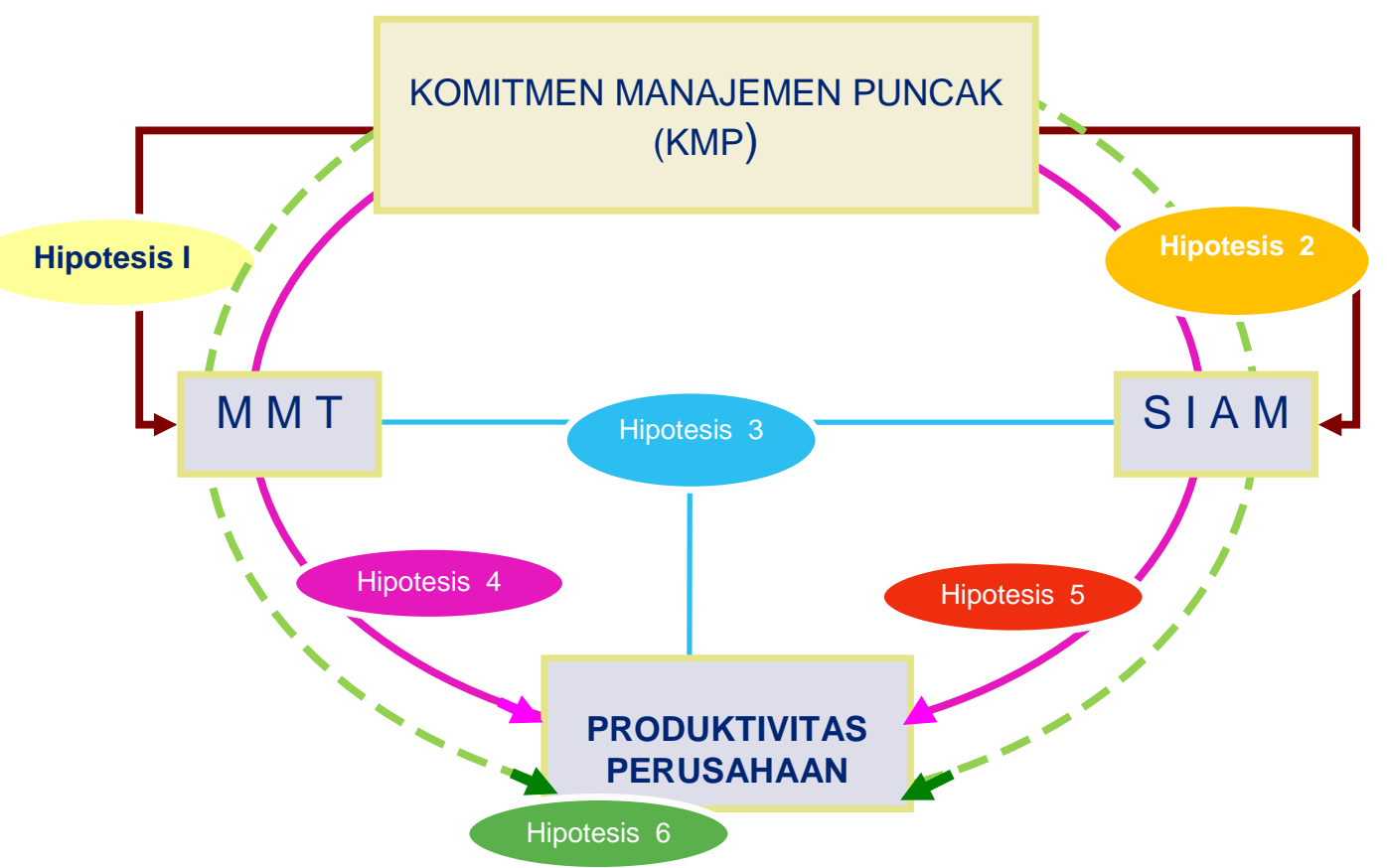

Gambar 2.

Paradigma Penelitian

Berdasarkan kerangka pemikiran dan paradigma penelitian dirumuskan hipotesis penelitian sebagai berikut :

1. Komitmen Manajemen Puncak berpengaruh positif dan signifikan terhadap Manajemen Mutu Terpadu;

2. Komitmen Manajemen Puncak berpengaruh positif dan signifikan terhadap Sistem Informasi Akuntansi Manajemen.

3. Manajemen Mutu Terpadu dan Sistem Informasi Akuntansi Manajemen secara simultan dan parsial berpengaruh positif dan signifikan terhadap Produktivitas Perusahaan.

4. Komitmen Manajemen Puncak melalui Manajemen Mutu Terpadu berpengaruh positif dan signifikan terhadap Produktivitas Perusahaan.

5. Komitmen Manajemen Puncak melalui Sistem Informasi Akuntansi Manajemen berpengaruh positif dan signifikan terhadap Produktivitas Perusahaan.

6. Komitmen Manajemen Puncak melalui Manajemen Mutu Terpadu dan Sistem Informasi Akuntansi Manajemen berpengaruh positif dan signifikan terhadap Produktivitas Perusahaan.

\section{METODE PENELITIAN}

Metode yang digunakan adalah Metode Survei Penjelasan (Explanatory Survey Method), dengan mengkaji empat variabel yang diteliti meliputi: (1) Komitmen Manajemen Puncak; (2) Manajemen Mutu Teepadu; (3) Sistem Innformasi Akuntansi Manajemen; dan (4) Produktivitas Perusahaan. Unit populasinya adalah perusahaan yang telah memperoleh sertifikat ISO Seri 9000 sejak tahun 2004-2006, dengan menggunakan Simple Random Sampling Technique ditetapkan unit sampling 69 
orang manajer produksi. Teknik pengumpulan data dilakukan dengan komunikasi tidak langsung dengan bantuan instrumen berupa kuesioner dan pedoman studi dokumentasi. Data yang digunakan adalah data primer dan data sekunder. Analisis data dilakukan secara deskriptif dengan bantuan statistika rata-rata nilai terbobot (Weighted Mean Score) dan secara inferensial dengan statistika analisis jalur (Path Analisys) dengan bantuan komputer.

\section{HASIL PENELITIAN}

Deskripsi dari masing-masing variabel, yaitu sebagai berikut:

Tabel 1. Rekapitulasi Hasil yang dicapai Masing-masing Variabel

\begin{tabular}{llccc}
\hline Variabel Penelitian & $\begin{array}{c}\text { Skor yang dicapai } \\
\text { (Actual) }\end{array}$ & $\begin{array}{c}\text { Skor Maks. } \\
\text { (Ideal) }\end{array}$ & $\begin{array}{c}\text { WMS } \\
(\%)\end{array}$ \\
\hline 1. & Komitmen Manajemen Puncak $(\boldsymbol{X})$ & 1914 & 2760 & 69,35 \\
\hline 2. & Manajemen Mutu Terpadu $\left(\boldsymbol{Y}_{1}\right)$ & 4793 & 7590 & 63,15 \\
\hline 3. & Sistem Informasi Akuntansi Manajemen $\left(\boldsymbol{Y}_{2}\right)$ & 7391 & 11385 & 64,92 \\
\hline 4. & Produktivitas Perusahaan $(Z)$ & 2903 & 4485 & 64,73 \\
\hline
\end{tabular}

Ket: WMS=Weighted Mean Score

Skor yang dicapai untuk Komitmen
Manajemen Puncak pada Perusahaan yang mendapat ISO Seri 9000 pada tahun 2004 dan 2006 secara keseluruhan adalah 1914 atau 69,35\% dari skor ideal 2760. Hal ini memberikan gambaran bahwa Komitmen Manajemen Puncak pada Perusahaan yang mendapat ISO Seri 9000 pada tahun 2004 dan 2006 secara keseluruhan termasuk kategori tinggi.

Skor yang dicapai untuk Manajemen Mutu Terpadu pada Perusahaan yang mendapat ISO Seri 9000 pada tahun 2004 dan 2006 secara keseluruhan adalah 4793 atau 63,15\% dari skor ideal 7590. Hal ini memberikan gambaran bahwa Manajemen Mutu Terpadu pada Perusahaan yang mendapat ISO Seri 9000 pada tahun 2004 dan 2006 secara keseluruhan, termasuk kategori tinggi. Artinya Manajemen Mutu Terpadu telah berjalan secara baik. Berikut ini uraian untuk masing-masing indikator yang membentuk Manajemen Mutu Terpadu.

Skor yang dicapai untuk Sistem Informasi Akuntansi Manajemen $\left(Y_{2}\right)$ pada Perusahaan yang mendapat ISO Seri 9000 pada tahun 2004 dan 2006 adalah 7391 atau 64,92\% dari skor ideal 11.385. Hal ini memberikan gambaran bahwa Sistem Informasi Akuntansi Manajemen pada Perusahaan yang mendapat ISO Seri 9000 pada tahun 2004 dan 2006 termasuk kategori tinggi, artinya Sistem Informasi Akuntansi Manajemen pada Perusahaan yang mendapat ISO Seri 9000 pada tahun 2004 dan 2006 telah memadai.

Skor yang dicapai produktivitas perusahaan yang mendapat ISO Seri 9000 pada tahun 2004 dan 2006 secara keseluruhan adalah 2903 atau 64,73\% dari skor ideal 4485. Hal ini memberikan gambaran bahwa produktivitas perusahaan manufaktur yang mendapat ISO Seri 9000 pada tahun 2004 dan 2006 secara keseluruhan, termasuk kategori tinggi. Artinya pencapaian produktivitas perusahaan sudah memadai. Variabel Produktivitas Perusahaan dalam penelitian ini diwakili oleh dua dimensi, yaitu keefektifan dan efisiensi. Keefektifan diukur melalui 6 pernyataan dan dimensi efisiensi diukur melalui 4 pernyataan. Skor dimensi keefektifan pada perusahaan manufaktur bersertifikat ISO seri 9000 adalah 67,68\% lebih besar daripada dimensi efisiensi yaitu sebesar 67,03\%. Hasil ini menunjukkan bahwa pada perusahaan-perusahaan manufaktur bersertifikat ISO seri 9000 keefektifan lebih diprioritaskan daripada efisiensi.

Hasil analisis koefisien jalur melalui pendekatan analisis regresi yang membentuk model diagram Struktur 1. Hasil perhitungan menunjukkan bahwa $p$-value $(0,000)<\alpha(0,05)$, maka hipotesis yang menyatakan Komitmen Manajemen Puncak berpengaruh positif dan signifikan terhadap Manajemen Mutu Terpadu dapat diterima. 


\section{Struktur 1:}

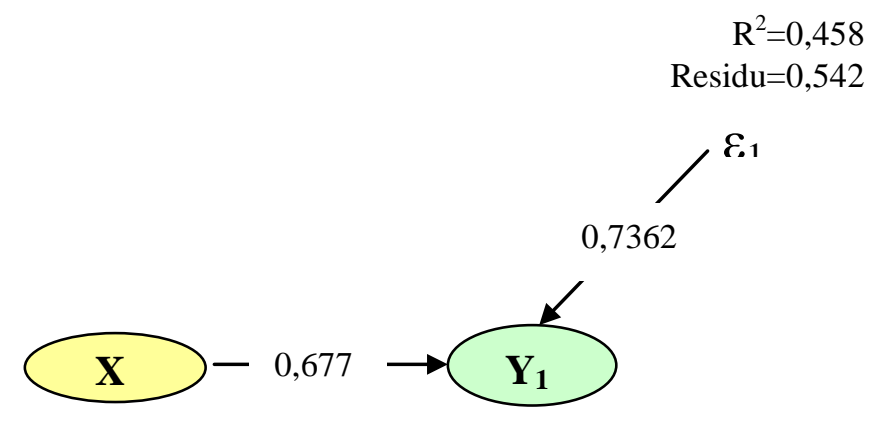

Gambar 3. Diagram jalur Hasil Pengujian Hipotesis 1 Pengaruh KMP $(X)$ Terhadap MMT $\left(Y_{1}\right)$

Berdasarkan gambar tersebut, diperoleh persamaan jalur yang menunjukkan pengaruh Komitmen Manajemen Puncak terhadap Manajemen Mutu Terpadu sebagai berikut:

$$
Y_{1}=0,667 X+0,542
$$

Dari persamaan ini dapat dijelaskan bahwa setiap perubahan komitmen manajemen puncak $(X)$ sebesar satu satuan akan menyebabkan perubahan pada implementasi manajemen mutu $\left(Y_{1}\right)$ sebesar 0,667. Besarnya pengaruh komitmen manajemen puncak $(X)$ terhadap implementasi manajemen mutu terpadu $\left(Y_{2}\right)$ mencapai $45,8 \%$, tersebut signifikan pada $\mathbf{\alpha}=0,05$ dan $p$-value $=0,000$. Sisanya sebesar $54,2 \%$ dipengaruhi oleh faktor lain. Hasil analisis koefisien jalur melalui pendekatan analisis regresi model diagram Struktur 2.

Hasil perhitungan menunjukkan bahwa $\mathrm{p}$ value (sig. $=0,000)<\alpha(\alpha=0,05)$. Dengan demikian $\mathrm{H}_{0}$ ditolak untuk menerima $\mathrm{H}_{\mathrm{i}}$. Dengan kata lain hipotesis yang menyatakan Komitmen Manajemen Puncak berpengaruh terhadap Implementasi Sistem Informasi Akuntansi Manajemen dapat diterima. Untuk lebih jelasnya dapat dilihat diagram jalur berikut ini.

Struktur 2:

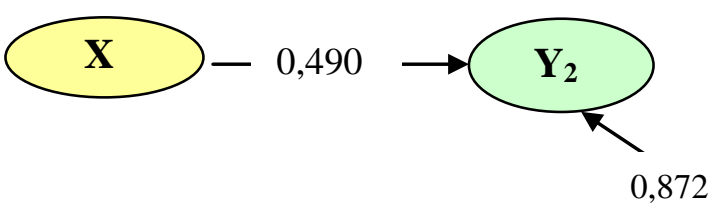

Gambar 4.

Diagram jalur Hasil Pengujian Hipotesis 2 Pengaruh KMP $(X)$ Terhadap SIAM $\left(Y_{2}\right)$<smiles>C[Te]</smiles>

$\mathrm{R}^{2}=0,240$

Residu $=0,760$
Berdasarkan gambar tersebut, diperoleh persamaan jalur yang menunjukkan pengaruh Komitmen Manajemen Puncak terhadap Sistem Informasi Akuntansi Manajemen sebagai berikut:

$$
Y_{2}=0,490 X+0,760
$$

Dari persamaan ini dapat dijelaskan bahwa setiap perubahan komitmen manajemen puncak $(X)$ sebesar satu satuan akan menyebabkan perubahan pada implementasi sistem informasi akuntansi manajemen $\left(Y_{2}\right)$ sebesar 0,490. Besarnya pengaruh komitmen manajemen puncak terhadap implementasi sistem informasi akuntansi manajemen (SIAM) mencapai 24\%, pengaruh komitmen manajemen puncak $(X)$ terhadap implementasi sistem informasi akuntansi manajemen $\left(Y_{2}\right)$ sebesar 24\% tersebut signifikan pada $\boldsymbol{\alpha}=0,05$ dan $p$-value $=0,000$. Sisanya sebesar 76\% dipengaruhi oleh faktor lain.

Hasil perhitungan menunjukkan bahwa pvalue $(0,000)<\alpha(0,05)$. Dengan demikian $H_{0}$ ditolak untuk menerima $\mathrm{H}_{\text {i. }}$ Dengan kata lain hipotesis yang menyatakan implementasi Manajemen Mutu Terpadu dan Sistem Informasi Akuntansi Manajemen terhadap Produktivitas Perusahaan dapat diterima. Untuk lebih jelasnya dapat dilihat diagram jalur berikut ini. 
Struktur 3:

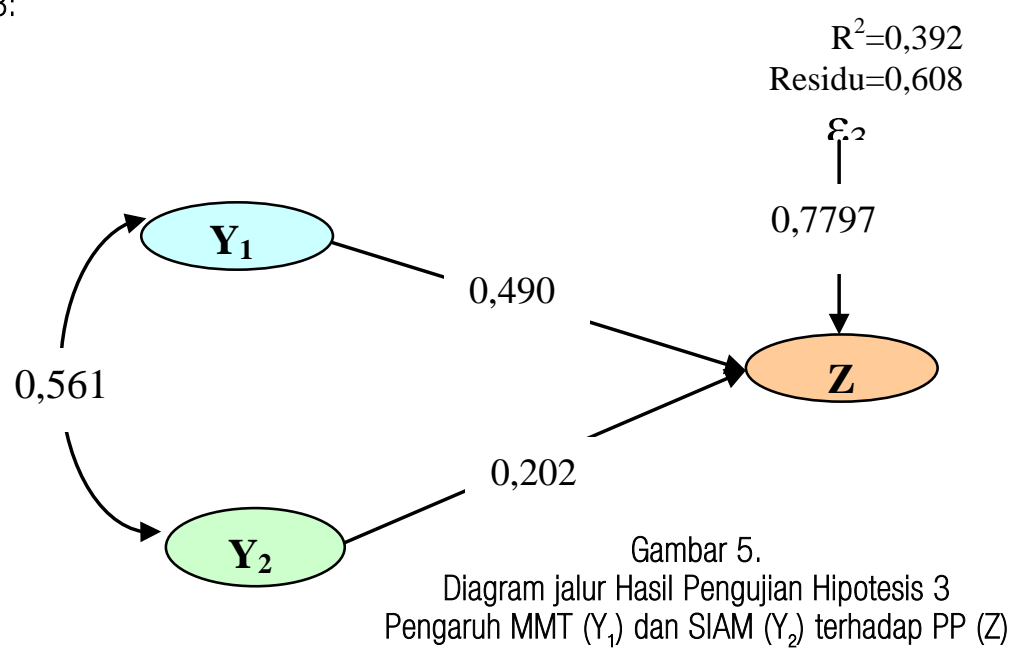

Berdasarkan gambar tersebut, diperoleh persamaan jalur yang menunjukkan pengaruh Manajemen Mutu Terpadu dan Sistem Informasi Akuntansi Manajemen terhadap Produktivitas Perusahaan sebagai berikut:

$$
Z=0,490 Y_{1}+0,202 Y_{2}+0,608
$$

Dari persamaan ini dapat dijelaskan bahwa setiap perubahan kebijakan implementasi manajemen mutu terpadu $\left(Y_{1}\right)$ sebesar satu satuan akan menyebabkan perubahan pada produktivitas perusahaan (Z) sebesar 0,490 dimana implementasi manajemen mutu terpadu $\left(Y_{2}\right)$ dianggap konstan atau dalam keadaan 0 , dan ini juga terjadi apabila implementasi sistem informasi akuntansi manajemen $\left(Y_{2}\right)$ sebesar satu satuan akan menyebabkan perubahan pada produktivitas perusahaan (Z) sebesar 0,202, dimana implementasi manajemen mutu terpadu $\left(Y_{1}\right)$ dalam keadaan konstan atau dalam keadaan 0 . Besarnya pengaruh manajemen mutu terpadu $\left(Y_{1}\right)$ secara parsial terhadap produktivitas Struktur 4: perusahaan (Z) mencapai 24,01\%, sedangkan besarnya pengaruh sistem informasi akuntansi manajemen $\left(Y_{2}\right)$ secara parsial mencapai 4,09. Perngaruh manajemen mutu terpadu $\left(Y_{1}\right)$ dan sistem informasi akuntansi manajemen $\left(Y_{2}\right)$ secara bersamasama mencapai 39,2\%. Pengaruh sebesar 39,2\% tersebut signifikan pada $\mathbf{\alpha}=0,05$ dan $p$ value $=0,000$. Sisanya sebesar 76 dipengaruhi oleh faktor lain.

Hasil perhitungan menunjukkan bahwa pvalue $(0,000)<\alpha(0,05)$, maka hipotesis yang menyatakan Komitmen Manajemen Puncak melalui implementasi manajemen mutu terpadu berpengaruh terhadap Produktivitas Perusahaan dapat diterima. Pengaruh KMP melalui MMT terhadap Produktivitas Perusahaan mencapai 16,3\%. Sedangkan sisanya dipengaruhi oleh faktor lain yang tidak diteliti dalam penelitian ini, yaitu mencapai 83,7\%.

$$
\mathrm{R}^{2}=0,163
$$

Residu $=0,837$

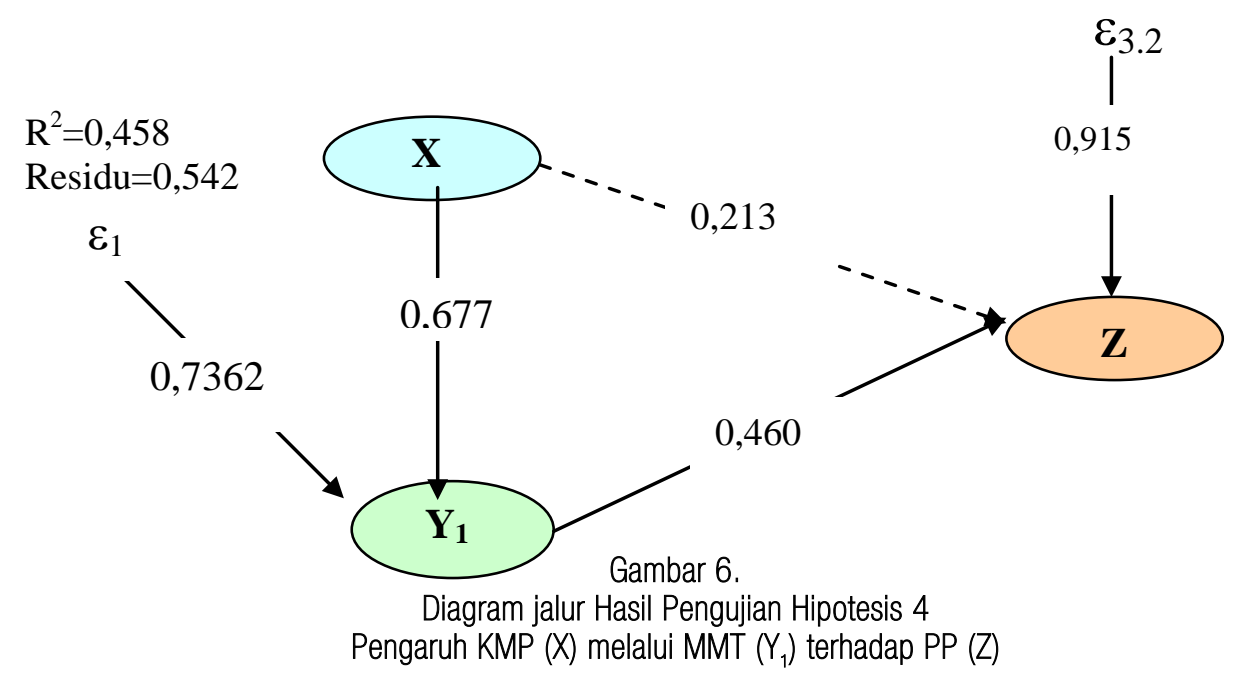


Berdasarkan gambar tersebut, diperoleh persamaan jalur yang menunjukkan pengaruh Manajemen Mutu Terpadu dan Sistem Informasi Akuntansi Manajemen terhadap produktivitas sebagai berikut:

$$
Z=0,213 X+0,46 Y_{1}+0,837
$$

Dari persamaan tersebut dapat dijelaskan bahwa setiap perubahan komitmen manajemen puncak $(X)$ sebesar satu satuan akan menyebabkan perubahan pada produktivitas perusahaan (Z) sebesar 0,213 dimana implementasi manajemen mutu terpadu $\left(Y_{1}\right)$ dianggap konstan atau dalam keadaan 0 , dan ini juga terjadi apabila kebijakan implementasi manajemen mutu terpadu $\left(Y_{1}\right)$ sebesar satu satuan akan menyebabkan perubahan pada produktivitas perusahaan (Z) sebesar 0,46, dimana komitmen manajemen puncak $(X)$ dalam keadaan konstan atau dalam keadaan 0. Besarnya pengaruh komitmen manajemen puncak $(X)$ melalui manajemen mutu terpadu $\left(Y_{1}\right)$ secara parsial terhadap produktivitas perusahaan (Z) mencapai 16,3\%,. Perngaruh sebesar $16,3 \%$ tersebut signifikan pada $\boldsymbol{\alpha}=0,05$ dan p-value $=0,000$. Sisanya sebesar $83,7 \%$ dipengaruhi oleh faktor lain.

Hasil perhitungan menunjukkan bahwa pvalue $(0,000)<\alpha(0,05)$. Dengan demikian $H_{0}$ ditolak untuk menerima $H_{\text {. }}$ Dengan kata lain hipotesis yang menyatakan Komitmen Manajemen Puncak melalui implementasi Sistem Informasi Akuntansi Manajemen berpengaruh terhadap Produktivitas Perusahaan dapat diterima.

Pengaruh KMP melalui SIAM terhadap Produktivitas Perusahaan mencapai 23,3\%. Sedangkan sisanya dipengaruhi oleh faktor lain yang tidak diteliti dalam penelitian ini, yaitu mencapai $76,7 \%$.

Untuk lebih jelasnya dapat dilihat diagram jalur dapat pada Gambar 4.5 sebagai berikut:

\section{Struktur 5:}

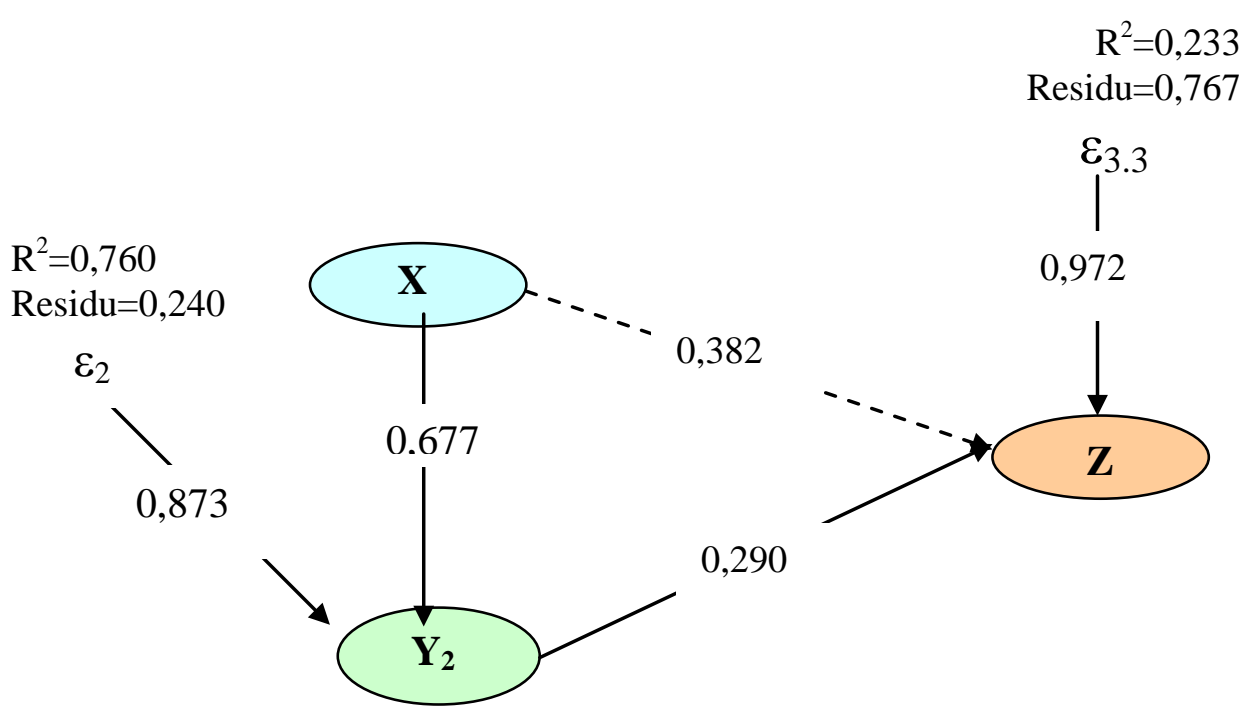

Gambar 7.

Diagram jalur Hasil Pengujian Hipotesis 5

Pengaruh KMP $(X)$ melalui SIAM $\left(Y_{2}\right)$ terhadap PP $(Z)$

Berdasarkan gambar tersebut, diperoleh persamaan jalur yang menunjukkan pengaruh Komitmen Manajemen Puncak melalui Sistem Informasi Akuntansi Manajemen terhadap Produktivitas Perusahaan sebagai berikut:

$$
Z=0,520 X+0,290 Y_{2}+0,925
$$

Dari persamaan tersebut dapat dijelaskan bahwa setiap perubahan komitmen manajemen puncak $(X)$ sebesar satu satuan akan menyebabkan perubahan pada produktivitas perusahaan (Z) sebesar 0,520 dimana implementasi sistem informasi akuntaansi manajemen $\left(Y_{2}\right)$ dianggap konstan atau dalam keadaan 0 , dan ini juga terjadi apabila kebijakan implementasi sistem informasi akuntansi manajemen $\left(Y_{2}\right)$ sebesar satu satuan akan menyebabkan perubahan pada produktivitas perusahaan (Z) sebesar 0,290, dimana komitmen manajemen puncak $(X)$ dalam keadaan konstan atau 
dalam keadaan 0. Besarnya pengaruh komitmen manajemen puncak $(X)$ melalui implementasi sistem informasi akuntansi manajemen $\left(Y_{2}\right)$ secara parsial terhadap produktivitas perusahaan (Z) mencapai 23,3\%,. Pengaruh sebesar 23,3\% tersebut signifikan pada $\mathbf{\alpha}=0,05$ dan $p$-value $=0,000$. Sisanya sebesar 76,7\% dipengaruhi oleh faktor lain.

Hasil perhitungan menunjukkan bahwa $p$ value $(0,000)<\alpha(0,05)$. Dengan demikian $H_{0}$ ditolak untuk menerima $H_{4}$. Dengan kata lain hipotesis yang menyatakan Komitmen Manajemen Puncak melalui implementasi MMT dan Sistem Informasi Akuntansi Manajemen berpengaruh terhadap Produktivitas Perusahaan dapat diterima. Pengaruh KMP melalui MMT dan SIAM terhadap Produktivitas Perusahaan mencapai 39,6\%. Sedangkan sisanya dipengaruhi oleh faktor lain yang tidak diteliti dalam penelitian ini, yaitu mencapai 60,4\%. Untuk lebih jelasnya dapat dilihat diagram jalur berikut ini

\section{Struktur 6}

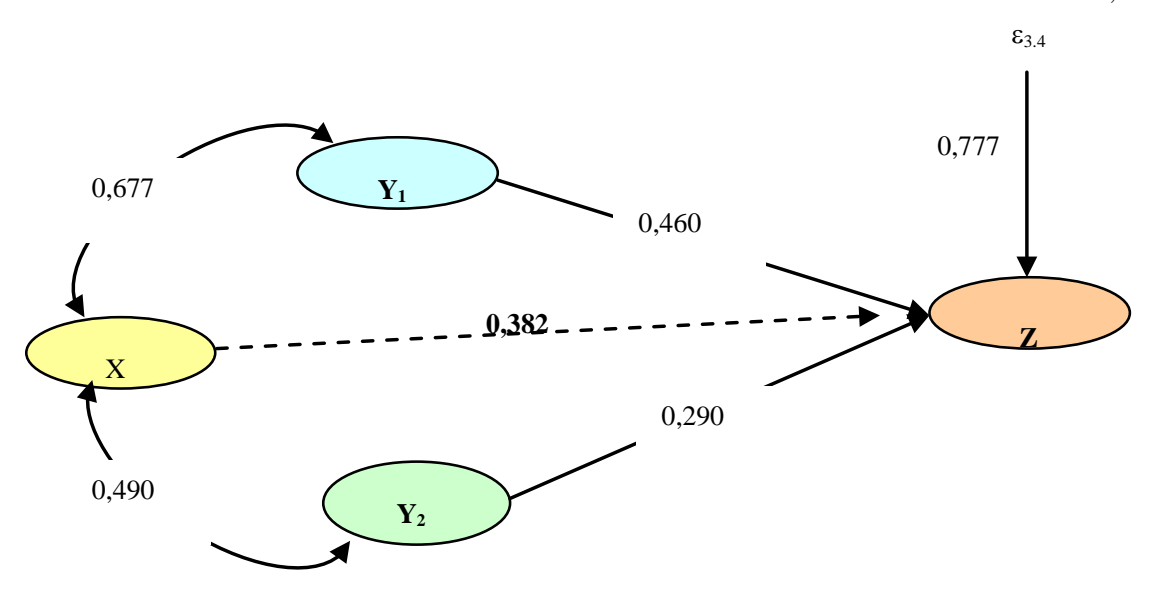

Gambar 8. Diagram Jalur Struktur 6, Hasil Pengujian Hipotesis 6

Dengan demikian pengaruh Komitmen Manajemen Puncak terhadap Produktivitas Perusahaan melalui Manajemen Mutu terpadu dan
Sistem Informasi Akuntansi Manajemen secara keseluruhan dapat digambarkan sebagai berikut:

Struktur Lengkap

$$
\mathrm{R}^{2}=0,458
$$

Residu $=0,542$

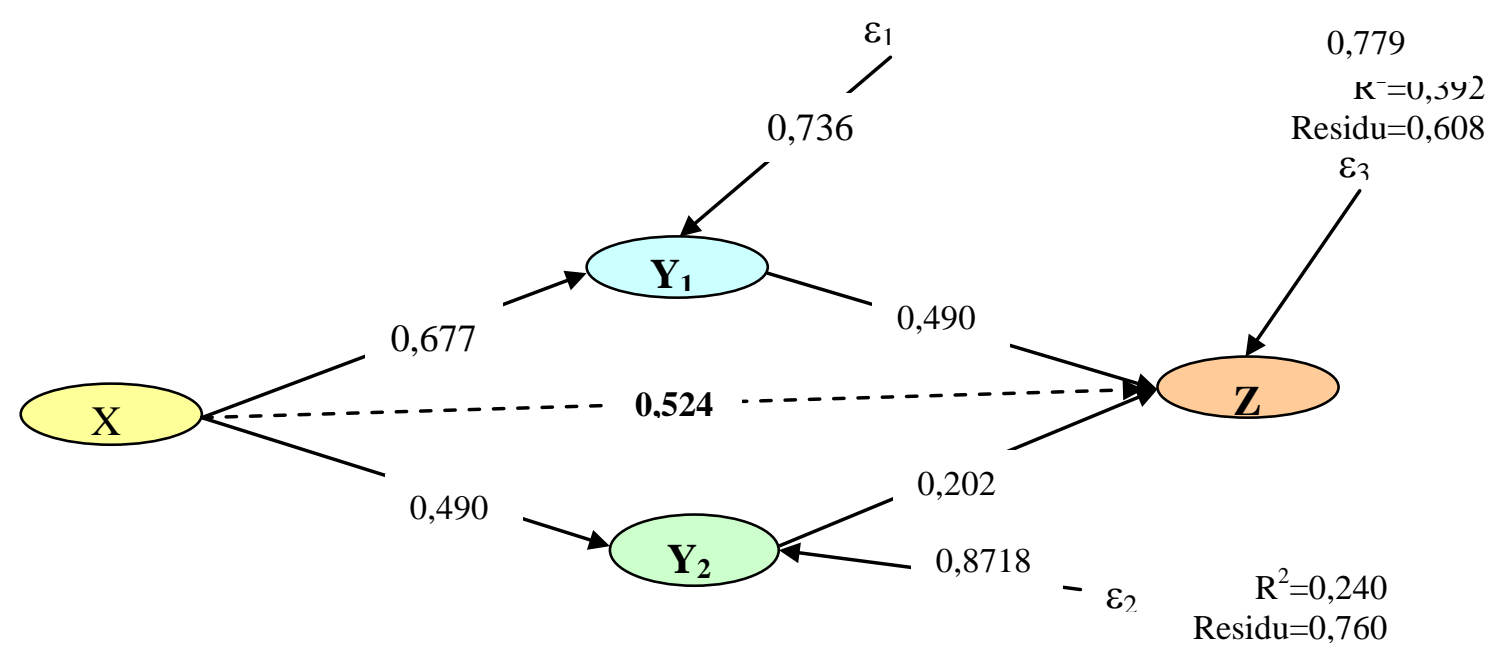

Gambar 9. Diagram Jalur Struktur Lengkap Hasil Pengujian Hipotesis Keseluruhan

Pengaruh Komitmen Manajemen Puncak terhadap Implementasi Manajemen Mutu Terpadu dan terhadap implementasi Sistem Informasi Akuntansi Manajemen maupun Implementasi Manajemen Mutu 
Tabel 15. Pengaruh $X$ Melalui $Y_{1}$ dan $Y_{2}$ terhadap $Z$

\begin{tabular}{|c|c|c|c|}
\hline Variabel & Langsung (\%) & Tidak Langsung & Total (\%) \\
\hline$X$ terhadap $Y_{1}$ & $(0,677)^{2}=0,4583$ atau 45,83 & - & 45,83 \\
\hline$X$ terhadap $Y_{2}$ & $(0,490)^{2}=0,2401$ atau 24,01 & - & 24,01 \\
\hline Y terhadap $Z^{\prime}$ & $(0,490)^{2}=0,2401$ atau 24,01 & - & 24,01 \\
\hline Y, terhadap Z & $(0,202)^{2}=0,0408$ atau 4,09 & - & 4,09 \\
\hline X terhadap Z & $(0,5$ & 524) & 27,46 \\
\hline$X$ melalui $Y_{1}$ terhadap $Z$ & - & $\begin{array}{l}(0,524)(0,677)(0,460) \\
=0,163\end{array}$ & 16,3 \\
\hline$X$ melalui $Y_{1}$ terhadap $Z$ & - & $\begin{array}{l}(0,382)(0,490)(0,290) \\
=0,233\end{array}$ & 23,3 \\
\hline$X, Y_{1}$ dan $Y_{2}$ terhadap $Z$ & - & $\begin{array}{l}(0,524)(0,677)(0,460) \\
+(0,382)(0,490)(0,290) \\
=0,396\end{array}$ & 39,6 \\
\hline
\end{tabular}

Berdasarkan Tabel 15 dapat diketahui bahwa :

1. Pengaruh komitmen manajemen puncak $(X)$ secara langsung terhadap manajemen mutu terpadu $\left(Y_{1}\right)$ mencapai 45,83\%, sisanya sebesar $54,17 \%$ dipengaruhi oleh faktor lain.

2. Pengaruh komitmen manajemen puncak $(X)$ secara langsung terhadap implementasi sistem informasi akuntansi manajemen $\left(Y_{2}\right)$ mencapai $24,01 \%$. Sisanya sebesar $75,99 \%$ dipengaruhi oleh faktor lain.

3. Pengaruh manajemen mutu terpadu $\left(Y_{1}\right)$ dan sistem informasi akuntansi manajemen $\left(Y_{2}\right)$ Terhadap produktivitas perusahaan (Z) mencapai $28.10 \%$, Sisanya sebesar $71,90 \%$ dipengaruh oleh faktor lain.
a. Pengaruh komitmen manajemen puncak $\left(Y_{1}\right)$ secara langsung terhadap produktivitas
perusahaan (Z) mencapai 24,01\%, sisanya dipengaruhi oleh faktor lain.
b. Pengaruh sistem informasi akuntansi manajemen $\left(Y_{2}\right)$ secara langsung terhadap produktivitas perusahaan ( Z ) mencapai 4,09\%. Sisanya sebesar 95,91\% dipengaruhi oleh faktor lain.

4. Pengaruh komitmen manajemen puncak $(X)$ melalui manajemen mutu terpadu $\left(Y_{1}\right)$ secara parsial terhadap produktivitas perusahaan (Z) mencapai 16,3\%. Sisanya sebesar 83,7\% dipengaruhi oleh faktor lain.

5. Pengaruh komitmen manajemen puncak $(X)$ melalui sistem informasi akuntansi manajemen $\left(\mathrm{Y}_{2}\right)$ secara parsial terhadap produktivitas perusahaan Z mencapai 0,15\%. Sisanya sebesar 99,85\% dipengaruhi oleh faktor lain.

6. Pengaruh kimitmen manajemen puncak $(X)$ melalui manajemen mutu terpadu $\left(Y_{1}\right)$ dan sistem informasi akuntansi manaajemen $\left(Y_{2}\right)$ secara simultan
Terhadap produktivitas perusahaan Z mencapai $39,6 \%$. Sisanya sebesar $60,4 \%$ dipengaruhi oleh factor lain.

Dengan demikian seluruh hipotesis yang diajukan dalam penelitian ini dapat diterima. Dengan demikian komitmen manajemen puncak melalui manajemen mutu terpadu dan sistem informasi akuntansi manajemen terhadap produktivitas perusahaan.

\section{KESIMPULAN}

Hasil penelitian menunjukkan bahwa seluruh hipotesis yang diajukan dapat diterima, yaitu:

(1) Komitmen manajemen puncak berpengaruh positif dan signifikan terhadap implementasi manajemen mutu terpadu pada perusahaan manufaktur yang bersertifikat ISO seri 9000. Dengan kata lain implementasi manajemen mutu terpadu ditentukan oleh komitmen manajemen puncak.

(2) Komitmen manajemen puncak berpengaruh positif dan signifikan terhadap sistem informasi akuntansi manajemen pada perusahaan manufaktur yang bersertifikat ISO seri 9000. Artinya sistem informasi akuntansi manajemen ditentukan oleh komitmen manajemen puncak.

(3) Implementasi manajemen mutu terpadu dan dan sitem informasi akuntansi manajemen berpengaruh positif dan signifikan terhadap produktivitas perusahaan manufaktur yang bersertifikat ISO seri 9000, baik secara parsial maupun secara simultan.

(4) Komitmen Manajemen Puncak melalui implementasi manajemen mutu terpadu berpengaruh positif dan signifikan terhadap 
produktivitas perusahaan manufaktur yang bersertifikat ISO seri 9000. Dengan kata lain komitmen manajemen puncak dapat mempengaruhi produktivitas melalui implementasi manajemen mutu terpadu.

(5) Komitmen Manajemen Puncak melalui sistem informasi akuntansi manajemen berpengaruh positif dan bermakna terhadap produktivitas perusahaan pada perusahaan manufaktur yang bersertifikat ISO seri 9000. Dengan kata lain komitmen manajemen puncak dapat mempengaruhi produktivitas melalui implementasi sistem informasi akuntansi manajemen.

(6) Komitmen Manajemen Puncak melalui implementasi manajemen mutu terpadu dan sistem informasi akuntansi manajemen berpengaruh positif dan signifikan terhadap produktivitas perusahaan manufaktur yang bersertifikat ISO seri 9000 Dengan kata lain produktivitas perusahaan turut ditentukan oleh komitmen manajemen puncak melalui implementasi manajemen mutu terpadu dan sistem informasi akuntansi manajemen.

\section{DAFTAR PUSTAKA}

Abernathy, M.A., Guthrie, C.H., Lillis Anne, 1995. The Impact of Manufacturing Flexibility on Management Control System Design, Journal of Accounting, Organizations and Society.

- Margareth A; Brownwell , Peter, 2000, Management control systems in research and development organization: The role of accounting, behavior and personnel controls, Journal of Accounting, Organizations \& Society (AOS), Vol: XXII, April-May 1997, pp. 233-248.

Ahire, S.L., Golhar,D.Y., Waller, M.A., 1996, Development and Validation of TQM Impementation Constructs, Decision Sciences, Vol. 27 No. 1. PP. 26-43

S.L., O'Shaughnessy,K.C., 1997, The Role of Top Management Commitment in Quality Management: An Empirical Analysis of the Auto Part Industry, International Journal of Quality Sciences, Vol. 3 No.1., pp 5-37.

Amstrong, Michael, 2003. Strategic Human Resourch Management: AGuide to Action. New Dehli: Crest Publishing House.

Anderson, J.C., Rungtusanatham, M., Schroeder, R.G., Devaraj, S., J.C., Shannon W. and
Sally K. Widener. 2006. Doing Quantitative Field Research in Management Accounting. In C.S. Chapman, A.G. Hopwood, and M.D. Shields (Eds.). Handbook of Management Accounting Research (Vol. 1). Oxford: Elsevier.

Andrew, J.P, Richard H.G. Field, 1998, Regrounding the Concept of Leadership, Leadership and Organization Development Journal, pp.123145

Andries de Grip, Inge Sieben, 2005. The Effect of Human Resourch Management on Small Firms Productivity and Employee Wages. Applied Economics. London: May, 20. Vol.37, Ed 9, pp.1047.

Anonymous, 2008. Top Trend s for 2008: Leadership, Talent, and Metrics will be Key, Human Resourch Focus. New York: Jan, Vol. 85, ed. 1., pp.8, 1 pgs.

Anthony, Leung K., Knowles, G and Gosh, S, 2002, Critical Success Factors of TQM Implementation in Hong Kong Industries, International Journal of Quality and Reliability Management, Vol. 19, No. 5, hal 551-66.

Arya, A., J. C. Fellingham and D. A. Schroeder. 2004. Aggregation and measurement errors in performance evaluation. Journal of Management Accounting Research (16): 93105.

Asian Productivity Organization, 2007, APO Data \& Analysis 2006, Tokyo.

Atkinson, Anthony A, Kaplan, R.S., Young, Mark S., 2004, Management Accounting. $4^{\text {th }}$ ed. Pearson Prentice Hall,.

Bailey, W., Jackson, S., Liu, K. and Salzinger, L., 2008, The Effects of Book Value versus Fair Value on Managerial Decision.

Blocher, E.J., Chen, K.H., Cokins, G., Lin, T.W.,2005, Cost Management - A Strategic Emphasis, McGraw Hill, 3rd ed,

Boudreau, John W, Peter M Ramstad, 2007. Beyod Human Resourch: The New Science of Human Capital, USA: Hanvard Business School.

Bouwens, Jan, Margareth A. Abernathy, 2000, The Concequences of Customization on Management Accounting System Design, Accounting, Organization and Society., pp 221-241.

Brah, S.A., Serene T.S.L. and Rao, B.M., 2002, Relationship Between TQM and Performance 
of Singapore Companies, International Journal of Quality and Reliability Management, Vol 19, No. 4, hal 356-379.

Brealey, Richard A., Myers, Stewart C. and Allen, Franklin, 2006. Principles of Corporate Finance, 8th edition, New York, NY McGraw-Hill Inc.

Bryant, Lisa, Denise Jones, and Sally K. Widener. 2004. Managing Value Creation Within the Firm: An Examination of Multiple Performance Measures. Journal of Management Accounting Research 16: 107131.

Burns, Jr. William J., Sharon M. McKinnon, 1993. Manager and Information, Journal of Management Accounting Research (JMAR), Volume 5, pp.87-102

Chapman, Ross, Paul Hyland, 2000, Strategy and Continuous Improvement in Small-to-Medium Australian Manufacturers, Integrated Manufacturing Systems Journal. Pp.56-57.

Chapman, Christopher S. Anthony G. Hopwood, Michael D. Shields., 2005, Handbook of Management Accounting Research. Elsevier.

Choe, Jong Min, 2004, The Relationship Among Management Accounting Information, Organizational Learning and Production Performance, Journal of Strategic Information Systems., pp.61-85.

Choe, Jong-min, 2004, Impact of Management Accounting Information and AMT on Organizational Performance, Journal of Information Technology, Vol. 19, hal 203222.

Cooper, Domald R, Pamela S. Schindler, 2000, Business Research Methods, Seventh edition, New York: McGraw-Hill Companies. Inc

Czarnecki, H., Schroer, Bernard, J., Adams, M., Spann, M.S., 2000, Continuous Process Improvement: When It Counts Most, Quality Progress. pp.54.

De Guerre, Don, 2004, Introduction to The Special Issue on Employee Empowerment, The Innovative Journal : The Public Sector Innovative Journal, Vol 9.

Finegold, David, 2007. Advance Total Management: Leadership Excellent. Provo, Nov, Vol. 21 Ed $2^{\text {nd }}$ pp.71, 2 pgs.

Gibson, James L., J.M. Ivancevich, J.H. Donnelly, Jr \& R. Konopaske, 2003, Organization,
Behavior, Structure, Process, McGraw-Hill, New York, $11^{\text {th }}$ ed.

Grandzol, J.R., Gershon,M., 1997, Which TQM Practices Really a Matter : An Empirical Investigation, Quality Management Journal.

Guven-Uslu, Pinar. 2008. Uses of Management Accounting Information for Benchmarking in NHS Trusts. Journal of Public Money \& Management__August. Vol. 28, Issue 4, pp. 239-246.

Hafeez, K., N. Malak, H. Abdel Meguid, 2006. A Framework for TQM to Achive Business Excellence, Total Quality Management and Business Excellence. Abingdon: Vol 17. Ed $9^{\text {th }}$ pp 1213.

Hammonds, Keith H., 2006. Why We Hate Human Resourch: Leadership Excellence. Provo: Feb Vol 23. Ed $2^{\text {nd }}$ pp20, 1 pgs.

Helo, Petri, Olli-Pekka Hilmola \& Ari Maunuksela, and Tauno Kekäle, 2000, Measurement of product development productivity. International Conference on Productivity and Quality Research 2000 (Jerusalem, Israel), vol. 1, pp. 173-178.

Hilmola, Olli-Pekka, Petri Helo, 2000, Streamlining Order Fulfillment Process Functions For Higher Productivity And Flexibility. Prosperita IV / 1 2000.pp.23-34

Hilton, Ronald W., Michael W.Maher, Frank H. Selto, 2004, Cost Management - Strategies for Business Decisions, Irwin, McGraw-Hill, New York.

Ibrahim, Mohammad Yussoff Daing Nasir Ibrahim \& Abdullah Jusoh, 2001, Competition, New Management Practices and The Emphasis Given to Non-Financial Indicators in Manufacturing Organization, Universitt Pendidikan Sultan Idris, Malaysia, pp 1-21.

JETRO, Japan External Trade Organization, 2008, Japanse - Affiliated Manufacturers in Asia: Survey 2008, Maret.

Jones, Gareth R. dan Hill, Charles W.L., 1998. Strategic Management. An Integrated Approach. $4^{\text {th }}$ Edtion. Boston Toronto: Houghton Company.

Kaplan, Robert S., 2006, The Competitive Advantage of Management Accounting, Journal of Management Accounting Research, Sarasota, Vol 18 hal. 127-136.

Kaynak, Hale, 2003, The Relationship Between Total Quality Management Practices and Their 
Effects on Firm Performance, Journal of Operations Management. pp.76-89.

Kondo, Yoshio, 2001, Quality CongresS, ASQ's: Annual Quality Congress Proceedings, Milwaukee, pp 1-9.

Kontoghiorghes, Constantine, 2003, Examining the Associations between Quality and Productivity Performance in a Service Organization, The Quality Management Journal,,Milwaukee, pp 32-43.

Kreitner, Robert, and Anggelo Kincki, 2005. Organization Behavior. $5^{\text {Th }}$ Edition. New Jersey; Englewood Cliffs: Prentice Hall Inc.

Kuncoro, Mudrajad, 2007. Ekonomika Industri Indonesia. Yogyakarta: Andi.

Lapierre, Jozee, 2000, Customer-Perceived Value in Industrial Context, Journal of Business and Industrial Marketing, vol 15 No. 2/3, pp. 122-140.

Laudon, Kenneth C., and Jane P. Laudone., 2007. Management Information Systems: Managing the Digital Firm. 10 Edition. Columbia:

Prentice Hall

LIPBI, 2000, 2003, 2004, 2005, 2006. Profile and Directory of Indonesian Companies ISO Centificate, Institute for Indonesian Development and Business Information, $4^{\text {th }}$ ed $-8^{\text {th }} \mathrm{Ed}$.

Luthan, Fred, 2006, Organizational Behavior, 10 edition, McGraw-Hill International Ed, Singapore.

Maiga, Adam S., 2005, Interaction Effects of Management Accounting Systems and Process Quality Management on Product Quality Performance, School of Business Administration, University of WisconsinMilwaukee, pp 1-34.

Mejia, Gomez, D.R. Balkin, R.L. Cardy, 2001, Managing Human Resources, Prentice Hall International, Inc. pp.36-49.

Otley, David T., Alexander Fakiolas, 2000, Reliance on Accounting Performance Measures : Dead End or New Beginning ? Accounting, Organizations and Society, hal 497-510.

Patterson, Malcolm G., Michael A. West, Tobby D. Wall, 2004, Integrated Manufacturing, Empowerment, and Company Performance, Journal of Organizational Behavior, Vol 25, hal 641-665.

Pearce II, John A. and Richard B. Robinson Jr. 2000. Strategic Management: Formulation,
Implementation and Control. Fifth Edition. Richard D Irwin, Inc. Burr Ridge, Illinois

Politis, John D., 2005, Dispersed Leadership Predictor of the Work Environment for Creativity and Productivity, European Journal of Innovation Management, Braford, Vol 8. ISS.2. pp. 182-205.

Powell, T.C.,1995, Total Quality Management as Competitive Advantage : A Review and Empirical Study, Strategic Management Journal. pp.78-100. , and William R., Jr, 2002, 9 Organizational Change Models, Futurics, St. Paul, Vol 26, ISS. 3/4, hal 20-46.

Robbins, Stephen, P., 2007, Organizational Behavior, $11^{\text {th }}$ ed. Prentice Hall International, Inc,

Roche, Evelyn, 2002, The Implementation of Quality Management Initiatives in the Context of Organizational Learning, Journal of European Industrial Training, Bradford, Vol 26, pp 1 14.

Roger, Erik, 2002, Quantitative Analysis of The Expectations and Realized Benefits of ISO 9000 Certification as Reported By Companies in Indonesia, California State University Dominguez Hills.

Sheeder, Frank, 2005. What Can a Comliance officer do to make an Organization More Commited to Compliance ?. Journal of Health Care Comliance, Frederick: Sep/Oct. Vol. 7 ed $5^{\text {th }}$ pp. 45, 4 pgs.

Terziovski, Mile, 2006, Quality Management Practices and Their Relationship with Customer Satisfaction and Poductivity Improvement, Management Research News, Vol 29, no. 7, hal 414-424.

Weidman, David, 2002, Redefining Leadership for the 21th Century, The Journal of Business Strategy, Vol.23.

Wheelen Thomas L, Hunger J. David, 2006, Strategic Management and Business Policy

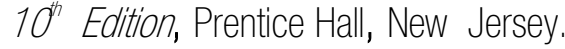

Williamson, Peter J, 2005, Strategies For Asia's New Competitive Game, The Journal of Business Strategy, vol 26, pp 37.

Wilson, D.C., Collier, D.A., 2000, An Empirical Investigation of the Malcolm Baldrige National Quality Award Causal Model, Decision Sciences.

Yukl, Gary, 2005, A. Leadership in Organizations, Englewood Cliffs, N.J. Prentice-Hall Inc. 